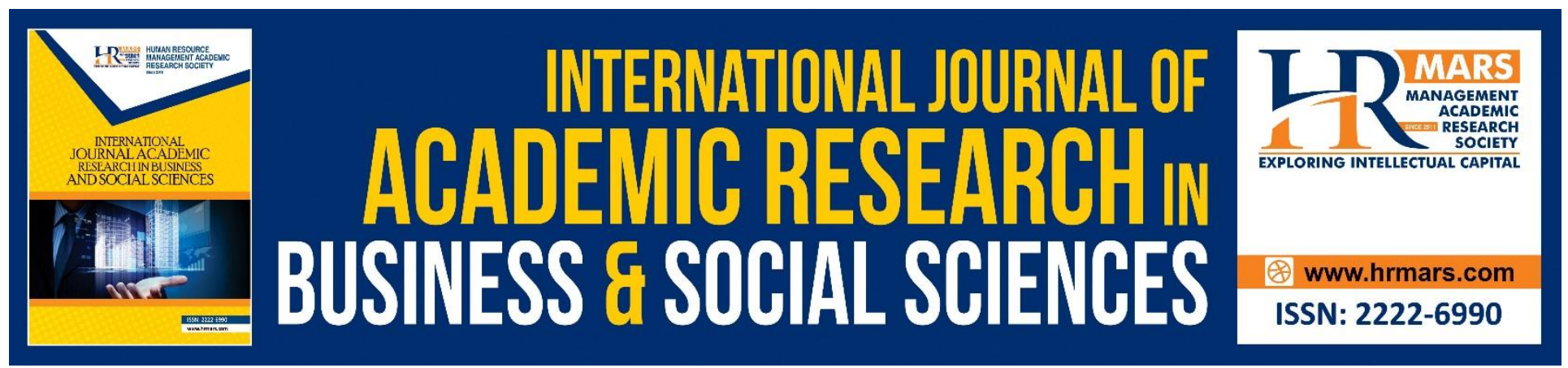

\title{
Administration of Punishment, Students' Test Anxiety, and Performance in Mathematics in Secondary Schools of Cross River State, Nigeria
}

\author{
Valentine Joseph Owan, Eno Etudor-Eyo, Uwase Uwase Esuong
}

To Link this Article: http://dx.doi.org/10.6007/IJARBSS/v9-i6/5963

DOI: $10.6007 /$ IJARBSS/v9-i6/5963

Received: 16 April 2019, Revised: 24 May 2019, Accepted: 02 June 2019

Published Online: 29 June 2019

In-Text Citation: (Owan, Eno, \& Uwase, 2019)

To Cite this Article: Owan, V. J., Eno, E.-E., \& Uwase, E. U. (2019). Administration of Punishment, Students' Test Anxiety, and Performance in Mathematics in Secondary Schools of Cross River State, Nigeria. International Journal of Academic Research in Business and Social Sciences, 9(6), 415-430.

Copyright: (c) 2019 The Author(s)

Published by Human Resource Management Academic Research Society (www.hrmars.com)

This article is published under the Creative Commons Attribution (CC BY 4.0) license. Anyone may reproduce, distribute, translate and create derivative works of this article (for both commercial and non-commercial purposes), subject to full attribution to the original publication and authors. The full terms of this license may be seen

at: $\underline{\text { http://creativecommons.org/licences/by/4.0/legalcode }}$

Vol. 9, No. 6, 2019, Pg. 415 - 430

http://hrmars.com/index.php/pages/detail/IJARBSS

JOURNAL HOMEPAGE

Full Terms \& Conditions of access and use can be found at http://hrmars.com/index.php/pages/detail/publication-ethics 


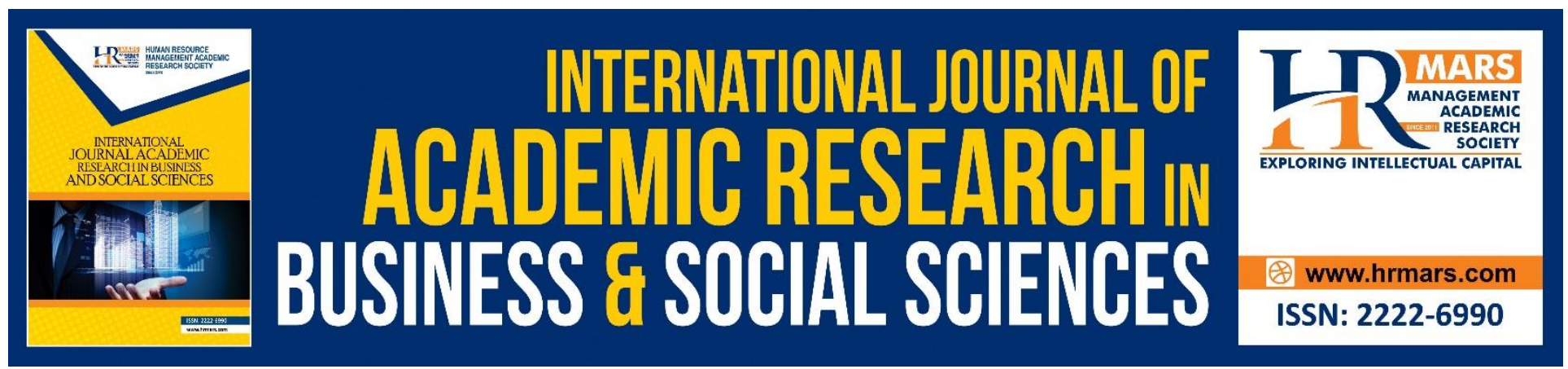

\title{
Administration of Punishment, Students' Test Anxiety, and Performance in Mathematics in Secondary Schools of Cross River State, Nigeria
}

\author{
Owan, Valentine Joseph \\ Department of Educational Administration and Planning, University of Calabar, Calabar, Nigeria. \\ Eno, Etudor-Eyo, Ph.D
}

Department of Educational Management and Curriculum Studies, University of Uyo, Uyo, Nigeria.

\section{Esuong Uwase Uwase}

Department of Science Education, University of Calabar, Calabar, Nigeria.

Email: owanvalentine@gmail.com, uwaseesuong@gmail.com, enoetudor@gmail.com

\begin{abstract}
This study assessed the administration of punishment, students' test anxiety, and performance in mathematics in secondary schools of Cross River State. Three null hypotheses were formulated following a correlational research design. Proportionate stratified random sampling technique was employed in selecting a sample of 2,554 respondents representing $5 \%$ of the population of 51,097 junior secondary school students distributed across 271 public secondary schools in Cross River State. Administration of Punishment Questionnaire (APQ) designed by the researchers, Test Anxiety Inventory (TAI) developed by Dawood et al., (2016), and Mathematics Achievement Test (MAT) designed by Owan (2012), were used as instruments for data collection. The null hypotheses were tested using one-way MANOVA), Pearson Product Moment Correlation, and Multiple regression analyses with the aid of SPSS v23. Findings revealed amongst others that administration of punishment has a significant influence on students' test anxiety and performance in mathematics $F$ $(6,5098)=24.149, p<.05$; Wilk's $\Lambda=0.945$, partial $\eta^{2}=.028$ on a joint basis; administration of punishment has a significant influence respectively on students' test anxiety $F(3,2550)=22.697$, $p<.0005$, partial $\eta^{2}=.026$ and performance in mathematics $F(3,2550)=23.090, P<.0005$, partial $\eta^{2}$ =.026; there is an inverse significant relationship $(r=-339, p<0.05)$ between students' tests anxiety and performance in mathematics. It was recommended that the use of corporal punishment should be totally abolished on strict grounds that it hurts the psychological disposition of learners resulting in a dip in their performance consequently.
\end{abstract}


INTERNATIONAL JOURNAL OF ACADEMIC RESEARCH IN BUSINESS AND SOCIAL SCIENCES

Vol. 9, No. 6, June, 2019, E-ISSN: 2222-6990 @ 2019 HRMARS

Keywords: Administration, Test anxiety, Punishment, Students' performance, Mathematics, MANOVA, Students.

\section{Introduction}

One of the greatest achievement of every school is to attain the objectives for which they were established. A secondary school can be said to have achieved its objectives when the performance of students in such a school is positive and high, when teachers discharge their duties according to prescribe rules and regulations, when the school climate is conducive at all times without conflicts amongst staff and students, and when the products raised from such school can compete favourably with those of the rest of the world (Offem, Arop, \& Owan, 2019).

Students' academic performance refers to the rate at which students are achieving the purpose for which they were sent to school. It is the degree at which students are achieving their educational goals (Owan, 2012). Student performance can be defined as the degree to which students are achieving the reasons or objectives for which they were sent to school. Simply put, students' performance refers to the learning outcomes of learners, it can be good or poor.

For a student to perform maximally in a test, the child must be studious, hardworking, dedicated, above all, be free from all forms of anxiety before or when taking tests. No matter how brilliant a student may portray, there will be underperformance in any test or examination if the student is depressed or emotionally unstable. Poor performance or high failure rates may contribute to unacceptable level of attrition, reduced graduate output and a high cost of education. This also results in a decline in terms of admission opportunities into tertiary institutions. Thus, students' academic performance is always a major topic of interest for educators and scholars (Jayanthi, Balakrishnan, SiokChing, Latiff \& Nasirudeen, 2014).

Notwithstanding, the huge benefits that positive performance brings, the state of students' performance in mathematics as well as other core subjects is below expectations. The poor academic performance of students in external mathematics examinations has further raised the minds of curious parents and other stakeholders to question the effectiveness of secondary schools in Nigeria. Reacting to this, Owan, Nwannunu, and Madukwe (2018) reported that secondary school students' academic performance generally is unstable, poor, and dwindling with many students struggling when they take classroom or external examinations. The high rate of examination malpractice by secondary school students is an indicator of poor students' academic performance (Arop, Ekpang, Nwannunu, \& Owan, 2018; Bassey, Owan, \& Agunwa, 2019).

In the past, the poor academic performance of students has been attributed to their study habits, lack of parental involvement, teachers' qualification, poor payment of teachers' salaries and what have you. However, with campaigns on the need to imbibe good study habits, many students have increased their study habits positively; many parents have been sensitized and as a consequence, are now active in training their children even against their own wellbeing; qualified teachers are now being employed yet there seem to be little or no improvement in the quality of students' academic performance in mathematics. It was based on this that the researchers undertook this study as a means of ascertaining whether the persistent poor academic performance of secondary students in mathematics has any association with the administration of punishment as well as students' test anxiety in Cross River State. 
Administration of punishment refers to the careful, systematic and proper meting out of stimuli with the consciousness of reducing or eliminating an observed negative behaviour from recurring, and to prevent the future repetition of such unwanted behavior. Barasa (2007) sees punishment as a disciplinary control technique and is used to reduce or prevent bad behaviours from re-occurring. Punishment by itself is not a pathway to appropriate behaviour because an individual punished for one form of inappropriate behaviour may replace it with different inappropriate behavior (Ngunyi, 2014). It can be used, however, to prevent guidelines of expected behavior through the enforcement of organizational policies. There are many ways punishment can be administered to a student including suspension, expulsion, corporal punishment, manual labour, detention, counselling, etc. In this study, only four forms of punishment were examined which include corporal punishment, suspension, discipline, and manual labour.

Test anxiety, on the other hand, is a psychological construct which depicts the emotional state of an individual prior to performing a task. Test anxiety of students may be borne out of fear or one's perception of a task to be performed. Hanem (2016) asserted that test anxiety is a devastating feeling of trouble and suffering among the students around the world and can be an overwhelming problem for students since it impairs their performance and comfort in the long run. Test anxiety has been found to impede on the academic performance of students in a test or examination (Effiom, \& Bassey, 2018). Other studies have also shown that examination has a relationship with increased anxiety and a situation engulfed with uncertainty/unfairness in letting them demonstrate their true achievements (Rana, \& Mahmood, 2010). Such uncertainties in the minds of students' limits their eventual performance in the test situation, directly causing a decline in the performance of students (Rana, \& Mahmood, 2010).

Some studies have provided empirical evidence connecting the administration of punishment and students' test anxiety to performance. These studies are hereby reviewed for a better understanding of various positions held by earlier scholars. Asonaba (2015) indicated that physical punishment made some students stop school, therefore, it was inferred that corporal punishment affects girls' enrolment and retention in schools. A study also found that a source of friction was created by students who were administered corporal punishment and such students showed a lack of interest in their academic work, began to exhibit unwanted behaviour, and a gradual academic decline; while students who were managed with adequate psychological treatment in place, developed learning interest, reflected friendly behaviour, and improved their long-term academic performance (Muhammad \& Muhammad, 2007).

Lomasontfo, Boyie, and Sithulisiwe (2017) showed that corporal punishment improves the academic performance of students, encourages students drop out from school, and also promotes stubbornness in learners. Guidance and counselling, manual work and positive discipline were recommended as effective disciplinary alternatives to corporal punishment. The study of Edward (2013) established that students punished using manual activities achieve improved behaviour, while denial of privileges was not helpful in boosting the behaviour of students. However, suspension from school was discovered as the most effective way of improving students' positive behaviour as well as guidance and counselling (Edward, 2013).

Olaitan, Mohammed and Ajibola (2013) disclosed that truancy, absenteeism, fighting, stealing and drug addiction among others are good examples of disciplinary problems experienced in schools. 
The study also revealed that political, economic, parental/home, social, school related factors, as well as peer group influence are the causes of disciplinary problems in schools. Findings from the study of Ngunyi (2014), indicated there are still common cases of indiscipline in public secondary schools, and recommended manual work as a good disciplinary alternative in secondary schools.

Offem, Arop, and Owan (2019) revealed that there is a significant relationship between students' perception towards the management of suspension and expulsion and their academic performance. Another study also showed that the use of expulsion as a punishment technique was the major predictor of students' performance, followed by giving of rewards. A study also showed that rewards can be a good way of promoting students' performance if followed with the administration of punishments (Nanyiri, 2014).

Some studies have also found that a significant relationship or influence exists between test anxiety scores and students' achievement scores (Rana, \& Mahmood, 2010; Okogu, Osah, \& Umudjere, 2016; Effiom \& Bassey, 2018). The results of some studies indicated that there is a statistically significant inverse correlation between test anxiety and students' grades and concluded that test anxiety has a significant and impact on students' academic performance (Hanem, 2016; Dawood, Al Ghadeer, Mitsu, Almutary, \& Alenezi, 2016).

In a related study, Ndirangu, Muola, Kithuka, and Nassiuma (2008) indicated that there is a significant difference $(P<0.01, t=-3.736)$ between test anxiety levels before and after examinations. It was disclosed that high anxiety is experienced before the examination in all subjects. It was also discovered that test anxiety affects both males and females equally. The study also found that test anxiety has no significant with students' academic performance $(r=0.06, p>.05)$

Using Mann Whitney and Spearman methods, a study revealed that students' test anxiety has a negative impact on their academic performance (DordiNejad, Hakimi, Ashouri, Dehghani, Zeinali, Daghighi, \& Bahrami, 2011). Another foreign study showed that the relationship between between test anxiety and academic achievement among adolescents is inverse and significant $(r=-0.23, p<.05)$ (Yousefi, Talib, Mansor, Juhari, \& Redzuan, 2010).

The review of related literature shows that there is a serious problem of students' anxiety and poor academic performance in Mathematics. Many studies have attempted to address these concerns, albeit the majority of the studies cited were conducted in foreign countries and other parts of the country. This study, therefore, contributes to the existing body of knowledge by assessing the nexus between the administrations of punishment, test anxiety, students' academic performance in Cross River State. The study used a unique approach with a focus specifically on the secondary education level to provide results that can be applied to solve educational problems locally.

\section{Purpose of the Study}

The broad goal of this study was to examine the administration of punishment, test anxiety, and students' performance in mathematics in secondary schools of Cross River State. The study in specific terms seeks to determine:

i. The influence of the administration of punishment on students' test anxiety and performance in mathematics.

ii. The relationship between the administration of punishment, students' test anxiety, and performance in mathematics. 
INTERNATIONAL JOURNAL OF ACADEMIC RESEARCH IN BUSINESS AND SOCIAL SCIENCES

Vol. 9, No. 6, June, 2019, E-ISSN: 2222-6990 @ 2019 HRMARS

iii. The composite influence of the administration of punishment and test anxiety on students' Hypotheses academic performance in mathematics.

The following null hypotheses were formulated to guide the study.

1. The influence of the administration of punishment on students' test anxiety and performance in mathematics is not statistically significant.

2. There is no significant relationship between the administration of punishment, students' test anxiety, and performance in mathematics

3. Administration of punishment and test anxiety has no significant composite influence on students' performance in mathematics.

\section{Materials and Methods}

This study was based on a correlational research design which aims to examine the relationship between two or more variables. This design was considered suitable for this study since the intent of this study includes amongst others, to examine the relationship between the administration of punishment, test anxiety, and students' performance in mathematics. The role of the study is to describe the relationships without any form of manipulation or control using data obtained from the instruments.

The population of this study comprised 51,097 junior secondary school students distributed across 271 public secondary schools in the area of study (Cross River State). Proportionate stratified random sampling technique was employed by the researchers in selecting a sample of 2,554 students. This selection implies that five percent of the entire population was selected, with the stratification based on the educational zones in Cross River State. The sample of this study is further presented in Table 1 below for clarity purposes.

TABLE 1

Sample distribution of the study showing the number of students selected from the three educational zones in Cross River State.

\begin{tabular}{lcc}
\hline Education zone & Population & Sample (5\%) \\
\hline Calabar & 16,785 & 839 \\
Ikom & 17,784 & 889 \\
Ogoja & 16,528 & 826 \\
Total & 51,097 & 2,554 \\
\hline
\end{tabular}

Source: Authors' computation

Three instruments were used for data collection. The first instrument is the Administration of Punishment Questionnaire (APQ) designed by the researchers with 24 items arranged on the revised four-point Likert scale of Strongly Agree (SA), Agree (A), Disagree (D), and Strongly Disagree (SD). The second instrument is the Test Anxiety Inventory (TAI) developed by Dawood et al (2016) with 20 items organized under four points Likert scale of Almost Never (AN), Sometimes (S), Often (O), Almost Always (AA). The third instrument is the Mathematics Achievement Test (MAT) designed by Owan (2012) with 10 objective test items in mathematics. The reliability of the instruments (TAI and MAT) were already established by Dawood et al., (2016) and Owan (2012) with a coefficient of Cronbach's 
Alpha $=0.871$ and 0.92 for TAI and MAT respectively, as established. However, the Gutman Split-Half reliability technique was used to ascertain the reliability of APQ with a coefficient of 0.881 revealing that the instrument was internally consistent for measurement.

The instruments were administered to the selected respondents, after the researchers had briefed them on the purpose of the study. The participants were also told to provide honest information with the assurance that all the information provided will be used purely for academic purpose without disclosure to anyone. After the administration of the instruments, the researchers retrieved all completed instruments from the respondents without any loss, representing a $100 \%$ rate of return of the administered instruments.

The completed instruments retrieved from the participants were carefully coded on a personby-item matrix using a spreadsheet program (MS-EXCEL, 2013). The items were all scored based on their respective scales and units of measurement. Descriptive statistics such as Mean and Standard Deviation were used to analyse the coded data, while inferential statistical methods such as multivariate analysis of variance (MANOVA), Pearson Product Moment Correlation, and Multiple regression were all employed (where applicable) in testing the null hypotheses at .05 alpha level. All computations were aided through the use of SPSS v23 and the results are presented in the following section.

\section{Results}

Hypothesis 1

The influence of the administration of punishment on students' test anxiety and performance in mathematics is not statistically significant. This hypothesis was tested at 0.05 level of significance using the multivariate analysis of variance. This statistical method was considered appropriate for this study because the data collected for this study met the nine assumptions for performing MANOVA. The independent variable was categorical and measured at the nominal scale. There two continuous dependent variables (students' test anxiety and performance in mathematics), the sample size was large enough $(n=2,554)$, there was absence of outliers, the variables were linearly correlated, absence of multicollinearity, Equality of covariance matrices was established through the Box's test, the Levene's test revealed that the error variance of the dependent variable is equal across groups. The results of the analysis are presented in Table 2, 3, and 4 below. 
INTERNATIONAL JOURNAL OF ACADEMIC RESEARCH IN BUSINESS AND SOCIAL SCIENCES Vol. 9, No. 6, June, 2019, E-ISSN: 2222-6990 @ 2019 HRMARS

TABLE 2

Descriptive statistics and assumptions of the multivariate analysis of variance results

\begin{tabular}{|c|c|c|c|c|}
\hline Variables & Admin. of punishment & Mean & SD & $\mathrm{N}$ \\
\hline \multirow[t]{5}{*}{ Students' Test Anxiety } & Corporal punishment & .61221 & .231586 & 1864 \\
\hline & Suspension & .57161 & .172226 & 175 \\
\hline & Expulsion & .52666 & .159418 & 59 \\
\hline & Manual Labour & .68986 & .184286 & 456 \\
\hline & Total & .62132 & .221505 & 2554 \\
\hline \multirow[t]{5}{*}{ Students' performance } & Corporal punishment & .61154 & .245960 & 1864 \\
\hline & Suspension & .59514 & .222050 & 175 \\
\hline & Expulsion & .51631 & .158968 & 59 \\
\hline & Manual Labour & .69968 & .179177 & 456 \\
\hline & Total & .62395 & .235082 & 2554 \\
\hline \multicolumn{5}{|c|}{ Box's Test of Equality of Covariance Matrices } \\
\hline Box's M & df1 & d & & Sig. \\
\hline 150.304 & 16.598 & 29479 & 345 & .243 \\
\hline \multicolumn{5}{|c|}{ Levene's Test of Equality of Error Variances } \\
\hline Variables & df1 & $\mathrm{d}$ & & Sig. \\
\hline Test Anxiety & 20.394 & 25 & & .083 \\
\hline SAPM & 19.097 & 25 & & .231 \\
\hline
\end{tabular}

a. Design: Intercept + Administration of punishment

The results presented in Table 2 showed that corporal punishment is the most commonly practiced punishment technique followed manual labour, suspension, and expulsion in that order. Out of these four punishment approaches, manual labour exerted the highest level of influence on students' test anxiety and performance in mathematics respectively. This is followed by corporal punishment, suspension, and expulsion. However, another test is required to determine whether the observed difference is statistically significant which shall be seen in Table 3.

The results of the Box's test (which is used in testing the null hypothesis that the observed covariance matrices of the dependent variables are not equal across groups) revealed a nonsignificant $(M=150.304, F=16.598, d f=9$ and 294793, $p>.05)$ value indicating that the assumption that there are equal covariance matrices across all the groups has been met. The $p$-value of the Levene's test was non-significant at .05 alpha level for students' test anxiety $(F=20.394, p>.05)$ and performance in mathematics ( $F=19.097, p>.05)$, indicating that the null hypothesis which states that the error variance of the dependent variable is not equal across groups is rejected. Thus the alternate hypothesis is retained implying that the Levene's test assumption for performing MANOVA has also been met. The multivariate test results presented in Table 3 was used in testing the null hypothesis one of this study. 
INTERNATIONAL JOURNAL OF ACADEMIC RESEARCH IN BUSINESS AND SOCIAL SCIENCES Vol. 9, No. 6, June, 2019, E-ISSN: 2222-6990 @ 2019 HRMARS

TABLE 3

Multivariate test showing the influence of administration on students' test anxiety and performance in mathematics in secondary schools of Cross River State

\begin{tabular}{llcccccc}
\hline Effect & & Value & F & Hyp. df & Error df & Sig. & Partial $\eta^{2}$ \\
\hline Intercept & Pillai's Trace & .791 & $4834.696^{\mathrm{b}}$ & 2.000 & 2549.000 & .000 & .791 \\
& Wilks' Lambda & .209 & $4834.696^{\mathrm{b}}$ & 2.000 & 2549.000 & .000 & .791 \\
& Hotelling's Trace & 3.793 & $4834.696^{\mathrm{b}}$ & 2.000 & 2549.000 & .000 & .791 \\
& Roy's Largest Root & 3.793 & $4834.696^{\mathrm{b}}$ & 2.000 & 2549.000 & .000 & .791 \\
\hline Admin of & Pillai's Trace & .055 & 23.825 & 6.000 & 5100.000 & .000 & .027 \\
punishment & Wilks' Lambda & .945 & $24.149^{\mathrm{b}}$ & 6.000 & 5098.000 & .000 & .028 \\
& Hotelling's Trace & .058 & 24.473 & 6.000 & 5096.000 & .000 & .028 \\
& Roy's Largest Root & .057 & $48.631^{\mathrm{c}}$ & 3.000 & 2550.000 & .000 & .054 \\
\hline
\end{tabular}

a. Design: Intercept + Administration of punishment

b. Exact statistic

c. The statistic is an upper bound on $\mathrm{F}$ that yields a lower bound on the significance level.

d. Computed using alpha $=.05$

The results presented in Table 3 revealed it was revealed that there was a significant influence of the administration of punishment on students' test anxiety and performance in mathematics. Thus it can be concluded that there is a statistically significant difference in students' tests anxiety and performance in mathematics levels respectively, based on the administration of punishment, $F(6$, $5098)=24.149, p<.05 ;$ Wilk's $\Lambda=0.945$, partial $\eta^{2}=.028$. The Wilk's Lambda indicates that 94.5 percent of the joint total variance in students' test anxiety and performance in mathematics is not accounted for by the administration of punishment. By implication, the administration of punishment explained $5.5 \%$ of the total variance in students' test anxiety and performance in mathematics jointly. However, in determining how the dependent variables differ based on the influence of the dependent variables the univariate ANOVA test (test between-subject effects) was performed as shown in Table 4. 
INTERNATIONAL JOURNAL OF ACADEMIC RESEARCH IN BUSINESS AND SOCIAL SCIENCES Vol. 9, No. 6, June, 2019, E-ISSN: 2222-6990 (C) 2019 HRMARS

TABLE 4

Univariate analysis of variance showing the influence of administration of punishment respectively on students' test anxiety and performance in mathematics in secondary schools.

\begin{tabular}{|c|c|c|c|c|c|c|c|}
\hline Source & Dependent Var. & Type III SS & df & MS & $\mathrm{F}$ & Sig. & $\begin{array}{c}\text { Partial } \\
\eta^{2} \\
\end{array}$ \\
\hline \multirow{2}{*}{$\begin{array}{l}\text { Corrected } \\
\text { Model }\end{array}$} & Test Anxiety & $3.258^{\mathrm{a}}$ & 3 & 1.086 & 22.697 & .000 & .026 \\
\hline & $\begin{array}{l}\text { Students' } \\
\text { perform. }\end{array}$ & $3.731^{\mathrm{b}}$ & 3 & 1.244 & 23.090 & .000 & .026 \\
\hline \multirow[t]{2}{*}{ Intercept } & Test Anxiety & 226.898 & 1 & 226.898 & $\begin{array}{c}4742.38 \\
2\end{array}$ & .000 & .650 \\
\hline & $\begin{array}{l}\text { Students' } \\
\text { perform. }\end{array}$ & 231.141 & 1 & 231.141 & $\begin{array}{c}4291.08 \\
7 \\
\end{array}$ & .000 & .627 \\
\hline \multirow{2}{*}{$\begin{array}{l}\text { Admin. of } \\
\text { punishment }\end{array}$} & Test Anxiety & 3.258 & 3 & 1.086 & 22.697 & .000 & .026 \\
\hline & $\begin{array}{l}\text { Students' } \\
\text { perform. }\end{array}$ & 3.731 & 3 & 1.244 & 23.090 & .000 & .026 \\
\hline \multirow[t]{2}{*}{ Error } & Test Anxiety & 122.004 & 2550 & .048 & & & \\
\hline & $\begin{array}{l}\text { Students' } \\
\text { perform. }\end{array}$ & 137.357 & 2550 & .054 & & & \\
\hline \multirow[t]{2}{*}{ Total } & Test Anxiety & 1111.190 & 2554 & & & & \\
\hline & $\begin{array}{l}\text { Students' } \\
\text { perform. }\end{array}$ & 1135.396 & 2554 & & & & \\
\hline \multirow{2}{*}{$\begin{array}{l}\text { Corrected } \\
\text { Total }\end{array}$} & Test Anxiety & 125.262 & 2553 & & & & \\
\hline & $\begin{array}{l}\text { Students' } \\
\text { perform. }\end{array}$ & 141.088 & 2553 & & & & \\
\hline
\end{tabular}

It can be seen from the results presented in Table 4 that administration of punishment has a significant influence respectively on students' test anxiety $F(3,2550)=22.697, p<.0005$, partial $\eta^{2}=$ .026 and students' performance in mathematics $F(3,2550)=23.090, P<.0005$, partial $\eta^{2}=.026$. It must be noted, however, that the null hypotheses in this section where all tested at 0.025 level of significance as a means of making a Bonferroni alpha correction to account for the multiple ANOVAs performed.

\section{Hypothesis 2}

There is no significant relationship between the administration of punishment, students' test anxiety, and academic performance. This null hypothesis was tested using the Pearson correlation matrix at .05 level of significance. The data for all the variables were scored continuously and the data were normally distributed without outliers, which fit the assumptions of Pearson correlation. The results of the analysis are presented in Table 5. 
INTERNATIONAL JOURNAL OF ACADEMIC RESEARCH IN BUSINESS AND SOCIAL SCIENCES

Vol. 9, No. 6, June, 2019, E-ISSN: 2222-6990 @ 2019 HRMARS

TABLE 5

Pearson correlation matrix showing the relationship between administration of punishment, students' test anxiety, and performance in mathematics in secondary schools.

\begin{tabular}{lccc}
\hline Variables & Mean & SD & N \\
\hline Administration of punishment & .35747 & .207776 & 2554 \\
Test Anxiety & .62132 & .221505 & 2554 \\
Students' performance & .62395 & .235082 & 2554 \\
\hline & & & $(3)$ \\
\hline (1) Administration of & $(1)$ & $.131^{* *}$ & $.102^{* *}$ \\
punishment & 1 & .000 & .000 \\
(2) Test anxiety & & 1 & -.339 \\
& & & .021 \\
(3) Students performance & & & 1 \\
\hline
\end{tabular}

**Correlation is significant at the 0.01 level (2-tailed)

The results as presented in Table 5 indicates that there is a significant relationship between administration of punishment and students' test anxiety $(r=.131, p<.05)$, as well performance in mathematics $(r=.102, p<.05)$. The results also showed that there is an inverse significant relationship $(r=-339, p<.05)$ between students' tests anxiety and performance in mathematics in Cross River State. Given all these statistical evidence, there were sufficient reasons to reject the null hypothesis stated above, and uphold the alternate hypothesis. This implies that there is a significant relationship between administration of punishment, students' test anxiety, and performance in mathematics.

Hypothesis 3

Administration of punishment and students' test anxiety has no significant composite influence on students' performance in mathematics. In this hypothesis administration of punishment and students' test anxiety served as independent variables to determine their composite effect on the dependent variable (students' performance in mathematics). The hypothesis was tested at the .05 alpha level using multiple regression analysis after checking for the assumptions, and the results are presented in Table 6. 
INTERNATIONAL JOURNAL OF ACADEMIC RESEARCH IN BUSINESS AND SOCIAL SCIENCES Vol. 9, No. 6, June, 2019, E-ISSN: 2222-6990 @ 2019 HRMARS

TABLE 6

Summary of multiple regression results showing the composite influence of administration of punishment and students' test anxiety on performance in mathematics

\begin{tabular}{lccccc}
\hline \multicolumn{1}{c}{$\mathrm{R}$} & $\mathrm{R}^{2}$ & & $\mathrm{Adj} . \mathrm{R}^{2}$ & & $\mathrm{SE}$ \\
& $.114^{\mathrm{a}}$ & .013 & & .012 & \\
\hline Model & $\mathrm{SS}$ & $\mathrm{Df}$ & $\mathrm{MS}$ & $\mathrm{F}$ & Sig. \\
\hline Regression & 1.843 & 2 & .921 & 16.880 & $.000^{\mathrm{b}}$ \\
Residual & 139.245 & 2551 & .055 & & \\
Total & 141.088 & 2553 & & & \\
\hline Model & $\mathrm{B}$ & $\mathrm{SE}$ & $\mathrm{Beta}$ & $\mathrm{t}$ & $\mathrm{Sig}$. \\
\hline (Constant) & .615 & .015 & & 40.607 & .000 \\
Test Anxiety & -.056 & .021 & -.053 & -2.667 & .008 \\
Admin. of punishment & .123 & .022 & .108 & 5.468 & .000 \\
\hline
\end{tabular}

a. Dependent variable: Students' performance in mathematics

From the results presented in Table 6, it was discovered that the two independent variables (administration of punishment and students' test anxiety) jointly account for $1.3 \%\left(R^{2}=.013\right.$, Adj. $R^{2}$ $=.012$ ) of the total variance in students' performance in mathematics with the remaining $98.7 \%$ explained by other independent variables not included in the model. The results also showed that there is a significant composite influence of the administration of punishment and students' test anxiety on students' performance in mathematics, $F(2,2551)=16.880, p<.05)$. Relatively, the results also showed that the administration of punishment was the highest predictor $(\beta=.108, t=5.468, p$ $<.05)$ of students' performance in mathematics, followed by students' tests anxiety $(\beta=.053, t=-$ $2.667, \mathrm{p}<.05)$

\section{Discussion of Findings}

This study established through its first finding that there is a significant influence of the administration of punishment on test anxiety and students' academic performance in mathematics $F$ $(6,5098)=24.149, p<.05$; Wilk's $\Lambda=0.945$, partial $\eta^{2}=.028$ on a joint basis. On an individual basis, this study discovered that administration of punishment has a significant influence on test anxiety $\mathrm{F}$ $(3,2550)=22.697, p<.0005$, partial $\eta^{2}=.026$ and students' academic performance in mathematics $F(3,2550)=23.090, P<.0005$, partial $\eta^{2}=.026$. This finding corroborates the studies of Rana and Mahmood (2010), Okogu, et al (2016), and Effiom and Bassey (2018) which revealed that which all revealed previously that administration of punishment has a significant influence on students' test anxiety and academic performance (Muhammad, 2007; Nanyiri, 2014; Asonaba, 2015; Muhammad et al, 2017; \& Offem, et al, 2019).

This study showed that corporal punishment is the most commonly practiced punishment technique followed by manual labour, suspension, and expulsion in that order. Manual labour exerted the highest level of influence on students' test anxiety and performance in mathematics respectively. This is followed by corporal punishment, suspension, and expulsion. This supports the study of Edward (2013) and Ngunyi (2014) which indicated there are still common cases of indiscipline 
INTERNATIONAL JOURNAL OF ACADEMIC RESEARCH IN BUSINESS AND SOCIAL SCIENCES Vol. 9, No. 6, June, 2019, E-ISSN: 2222-6990 @ 2019 HRMARS

in public secondary schools, and recommended manual work as a good disciplinary alternative in secondary schools. In popular usage, it is very common to find many teachers utilizing corporal punitive approaches such as caning, slapping, boxing, kicking, and even knocking. These approaches are commonly used, such frequent usage has not much influence when compared with manual labour.

The second finding of this study exposed that there is a significant relationship between administration of punishment and students' test anxiety $(r=.131, p<.05)$ as well as students' performance in mathematics $(r=.102, p<.05)$. This finding is in line with the finding from the studies of Muhammad (2007) Rana and Mahmood (2010), Nanyiri (2014) Asonaba (2015), Okogu, et al (2016), Muhammad et al (2017), Effiom and Bassey (2018), and Offem, et al (2019) which all revealed that the use of punishment has a significant nexus with students' performance. This positive correlation established in this study suggests that as teachers increase the administration of punishment (especially using the right techniques) in eliminating unwanted stimuli, students' performance in mathematics will witness an increase (other factors kept constant). This is because punishment when properly administered eliminates truant behaviors manifested by students. Such truant behaviors as listed by Olaitan et al., (2013) include absenteeism, fighting, stealing, and drug addiction among others. These negative attitudes if allowed to persist will decline the study pattern of secondary school learners consequently leading to a drop in their performance in mathematics and/or other subjects.

The results of this study further showed that there is an inverse significant relationship ( $r=-$ $339, p<.05)$ between students' tests anxiety and performance in mathematics in Cross River State. Other studies also indicated that there is highly statistically inverse correlation between total test anxiety and grade point average and concluded that test anxiety has a significant and efficient impact on students' performance (Yousefi, et al., 2010; Hanem, 2016; Dawood, et al., 2016). This finding, however, disagrees with the study of Ndirangu, et al (2008) which discovered that test anxiety has no significant nexus with students' academic performance $(r=0.06, p>.05)$.

The inverse relationship established in the present implies that students' performance in mathematics increases when as their test anxiety in the subject decreases (other things being equal) and vice versa. This result is not surprising because the poor psychological state of learners creates anxiety in them which prevents them from reasoning well during mathematics examinations requiring critical thinking and calculations.

It was revealed through the third major finding of this study that there is a significant composite influence of administration of punishment and students' test anxiety on their performance of students in mathematics, $F(2,2551)=16.880, p<.05)$ with administration of punishment being the highest positive predictor $(\beta=.108, t=5.468, p<.05)$ and tests anxiety being the lowest negative $(\beta=.053, t=-2.667, p<.05)$ of students' performance in mathematics. This tells you that the presence of both the administration of punishment and test anxiety in a school will affect students' performance in mathematics. However, the clear disparity between the two is that, while the administration of punishment is exerting a positive effect, test anxiety is negatively affecting students' performance in mathematics. This finding further strengthens the correlation results established earlier in the present study. 


\section{Conclusion}

It was concluded generally that there is a nexus between the administration of punishment, students' test anxiety and performance in mathematics in Cross River State. The administration of punishment has a significant influence on students' test anxiety and performance in mathematics jointly and respectively. Administration of punishment has a positive effect while students test anxiety has a negative effect on performance in mathematics. When jointly in place, the administration of punishment and students' test anxiety have a significant composite effect on students' performance in mathematics, with the administration of punishment being the highest positive predictor. Corporal punishment is the most commonly practiced disciplinary technique while manual labor has the highest effect on both students' test anxiety and performance in mathematics.

\section{Recommendations}

Based on the finding of this study, the following recommendations were made:

i. The use of corporal punishment should be totally abolished on strict grounds that it hurts the psychological disposition of learners resulting in a dip in their performance consequently.

ii. Manual labor should only be administered for serious offenses like bullying, fighting, absenteeism, stealing, and others, while disciplinary measures such as verbal warnings and written queries are recommended for minor offenses like noise making, gossiping, disrespect, inattentiveness, jumping through the window, and so on.

iii. Mathematics teachers in secondary schools should ensure that the psychological state of learners during the teaching-learning process is given utmost concern. This will enable them to identify learners passing through depression and/or anxiety in the classroom, and will better be placed to helping such learners.

iv. The government at all levels should work harmoniously and provide each school in the state with at least five professional counsellors to cater for the vocational, educational, and persona-social needs of students.

v. Professional counsellors as well as para-counsellors (teachers) in schools should ensure that regular counselling sessions are held in schools to boost the psychological strengths of students and eliminate the phobia usually associated with the learning of mathematics on the part of students.

\section{References}

Anaduaka, U. S. \& Okafor, C. F. (2013). Poor performance of Nigerian students in mathematics in Senior Secondary Certificate Examination (SSCE): What is not working? JORIND, 11(2), 1 - 5.

Arop, F. O., Ekpang, M. A., Nwannunu, B. I., \& Owan, V. J. (2018). Personnel management and corrupt academic practices in universities in Cross River State, Nigeria. International Journal of Economics, Commerce and Management, 6(9), 405 - 419.

Asonaba, K. A. (2015). Effects of corporal punishment on girl's enrolment and retention in the Techiman Municipality. American Journal of Educational Research, 3(11), 1455-1468

Barasa, J. M. (2007). Educational Organization and management. Nairobi: Jomo Kenyatta foundation. 
INTERNATIONAL JOURNAL OF ACADEMIC RESEARCH IN BUSINESS AND SOCIAL SCIENCES

Vol. 9, No. 6, June, 2019, E-ISSN: 2222-6990 @ 2019 HRMARS

Bassey, B. A., Owan, V. J. \& Agunwa, J. N. (2019). Quality assurance practices and students' performance evaluation in universities of South-South Nigeria: A structural equation modelling approach. British Journal of Psychology Research, 7(3), 1-13.

Dawood E., Al Ghadeer, H., Mitsu, R., Almutary, N., \& Alenezi, B. (2016). Relationship between test anxiety and academic achievement among undergraduate nursing students. Journal of Education and Practice, 7(2), $57-65$.

DordiNejad, F. G., Hakimi, H., Ashouri, M., Dehghani, M., Zeinali, Z., Daghighi, M. S., \& Bahrami, N. (2011). On the relationship between test anxiety and academic performance. Procedia Social and Behavioral Sciences, 15, 3774-3778. doi:10.1016/j.sbspro.2011.04.372

Edward, O. N. (2013). Effects of disciplinary strategies on students' behaviour in public secondary schools in Matungulu District, Machakos County in Kenya. M.Ed thesis submitted to the department of Project Planning and Management of the University of Nairobi.

Effiom, B. E. \& Bassey, B. A. (2018). Test anxiety, self-esteem and academic performance among secondary school students in Cross River State, Nigeria. International Journal of Education and Evaluation, 4(9), $18-27$.

Hanem, A. A. (2016). Exploring the relationship between test anxiety and academic achievement among female nursing students at Zagazig University. IOSR Journal of Nursing and Health Science (IOSR-JNH S), 5(5), 43 - 48. DOI: 10.9790/1959-0505084348

Jayanthi, S. V., Balakrishnan, S., SiokChing A. L., Latiff N. A. A. \& Nasirudeen A. M. A. (2014). Factors contributing to academic performance of students in a tertiary institution in Singapore. American Journal of Educational Research, 2(9), 752 - 758.

Lomasontfo, K. D, Boyie, S. D, \& Sithulisiwe, B. (2017). The use of corporal punishment and its effects on students' academic performance in Swaziland. IOSR Journal of Humanities and Social Science (IOSR-JHSS), 22(12), 53-61

Mamman, M. \& Eya, S. D. (2014). Trends analyses of students' mathematics performance in West African Senior Secondary Certificate Examination from 2004 to 2013: Implication for Nigeria's vision 20:2020. British Journal of Education, 2(7), 50-64).

Muhammad, S. A \& Muhammad, S. R. (2007). Effects of corporal punishment and psychological treatment on students' learning and behavior. Journal of Theory and Practice in Education; 3(2), 171-180

Ndirangu, G. W., Muola, J. M., Kithuka M. R., \& Nassiuma D. K. (2008). An investigation of the relationship between test anxiety and academic performance in secondary schools in Nyeri District, Kenya. Global Journal of Educational Research, 7(1\&2), 1 - 7.

Ngunyi, J. C. (2014). Influence of alternative disciplinary measures on students' discipline in public secondary schools in Nyandarua south sub-county, Kenya. M.Ed thesis submitted to the Department of Educational Administration, University of Nairobi.

Ngunyi, J. C. (2014). Influence of alternative disciplinary measures on students' discipline in public secondary schools in Nyandarua south sub-county, Kenya. M.Ed thesis submitted to the Department of Educational Administration, University of Nairobi.

Offem, O. O., Arop, F. O., \& Owan, V. J. (2019). Students' perception towards management of discipline and their academic performance in Cross River State. Global Journal of Academic Research (GJAR), 3(1), $34-40$. 
INTERNATIONAL JOURNAL OF ACADEMIC RESEARCH IN BUSINESS AND SOCIAL SCIENCES

Vol. 9, No. 6, June, 2019, E-ISSN: 2222-6990 (C) 2019 HRMARS

Okogu J. O., Osah M. \& Umudjere, S. O. (2016). Examination anxiety and students' academic performance: Social studies approach. International Journal of Educational Policy Research and Review, 3(1), 1-5.

Olaitan, T., Mohammed A. N. \& Ajibola, A. L. (2013). Management of disciplinary problems in secondary schools: Jalingo Metropolis in focus. Global Journal of Human Social Science Linguistics \& Education, 13(14), 6-19

Owan, V. J. (2012). Some causes of poor performance of pupils in primary school mathematics. A case study in Akamkpa L.G.A Cross River State. DOI: 10.2139/ssrn.3221784 Retrieved from https://goo.gl/NTTxqc

Owan, V. J., Nwannunu, B.I. \& Madukwe E. C. (2018). Problems of school management and students' academic performance in secondary schools in Calabar Education Zone, Cross River State, Nigeria. International Journal of Research and Innovation in Social Science (IJRISS), 2(10), 120127.

Rana, R. A. \& Mahmood, N. (2010). The relationship between test anxiety and academic achievement. Bulletin of Education and Research, 32(2), $63-74$.

Yousefi, F., Talib, M. A., Mansor, M. B., Juhari, R. B., \& Redzuan, M. (2010). The relationship between test-anxiety and academic achievement among Iranian Adolescents. Asian Social Science, 6(5), 100-105. 